Monográfico: Reflujo Vesicoureteral

Arch. Esp. Urol., 61, 2 (254-257), 2008

\title{
MODIFICATION OF THE STING PROCEDURE FOR VESICOURETERAL REFLUX: URETERAL REPOSITIONING AND INJECTION
}

\author{
N. Capozza and P. Caione.
}

Division of Pediatric Urology. Department of Nephrology and Urology. Bambino Gesù. Children's Hospital. Rome. Italy.

Summary.- OBJETIVE: Over the past 20 years endoscopic treatment (ET) of vesicoureteral reflux (VUR) has changed the algorithm of reflux management. We describe a modification of the standard subureteral injection (STING) that has contributed to the increased success rate of this procedure.

METHODS: Between January 2006 and December 2006 192 children, 5 months to 10 years old (mean age 2.8 years) underwent endoscopic treatment for VUR, with injection of dextranomer/hyaluronic acid copolymer (Dx/HA). Standard STING procedure was used in 165 patients (235 ureters). A modified STING procedure, here described as "ureteral repositioning and injection" (URI) was used in 27 patients 138 ureters). In the URI technique, the needle was inserted as for standard STING; subsequently the distal part of the ureter was

\author{
Nicola Capozza \\ Division of Paediatric Urology \\ Bambino Gesù. Children's Hospital \\ Piazza S. Onofrio, 4 \\ 00165 Rome. (Italy). \\ capozza@opbg.net
}

raised and levered towards the lumen of the bladder; Dx/HA was then injected. Renal/bladder ultrasound was performed 1 month after treatment and a voiding cystourethrogram (VCUG) at 4-6 months.

RESULTS: After a single injection the VCUG showed no reflux in 203 ureters of STING group (86\%) and in 34 ureters of URI group (91\%). Mean injected volume of Dx/HA was $0.7 \mathrm{ml}$ $(0.3-1.8 \mathrm{ml})$ for STING and $0.4 \mathrm{ml}(0.3-0.8 \mathrm{ml})$ for URI.

CONCLUSION:The modified STING we have proposed, presents some advantages. It is very easy to perform and needs less material to inject. The ureteral repositioning into the bladder, with the support of the implanted material, may reconstruct a true flap-valve mechanism, without the risk of ureteral obstruction.

Keywords: Vesicoureteral reflux. Endoscopy. Pediatrics. Dextranomer/hyaluronic acid copolymer.

Resumen.- OBJECTIVO: Durante los últimos 20 años el tratamiento endoscópico del reflujo vesicoureteral (RVU) ha cambiado el algoritmo del manejo de esta entidad. Describimos una modificación de la inyección subureteral estándar (STING) que ha contribuido a aumentar el porcentaje de éxitos de este procedimiento.

MÉTODOS: Entre enero y diciembre del 2006, 192 niños, entre cinco meses y diez años de edad ledad mediana 2,8 años), fueron sometidos a tratamiento endoscópico del reflujo vesico ureteral con inyección de copolímero de dextranomero/ ácido hialurónico (DX/HA). El procedimiento STING estándar se utilizó en 165 pacientes (235 uréteres). Un procedimiento STING modificado, descrito aquí como "reposicionamiento ureteral e inyección" (RUI) se utilizó en 27 pacientes (38 uréteres). En la técnica de reposicionamiento ureteral e inyección se inserta la aguja como para un procedimiento STING estándar y posteriormente se eleva la porción distal del uréter haciendo palanca hacia la luz vesical y entonces se inyecta 
el DX/HA. Se realizó ecografía renal/vesical un mes después del tratamiento y una cistouretrografía miccional seriada (CUMS) a los 4-6 meses.

RESULTADOS: Después de una única inyección la CUMS mostró ausencia de reflujo en 203 uréteres del grupo STING (86\%) y 34 uréteres del grupo RUI (91\%). El volumen medio de DX/HA inyectado fue de 0,7 ml $(0,3-7,8 \mathrm{ml})$ en el STING y $0,4 \mathrm{ml}(0,3-0,8 \mathrm{ml}$ ) en el RUI.

CONCLUSIONES: La modificación del STING que proponemos tiene algunas ventajas. Es muy fácil de realizar y necesita menos material inyectable. El reposicionamiento ureteral hacia la vejiga, con el apoyo del material implantado, puede reconstruir un auténtico mecanismo de válvula-flap sin riesgo de obstrucción ureteral.

Palabras clave: Reflujo vesico ureteral. Endoscopia. Pediatría. Copolímero de dextranomero/ácido hialurónico.

\section{INTRODUCTION}

Since its introduction in 1982, endoscopic treatment of vesicoureteral reflux (VUR) has gained popularity for its low invasiveness and high efficacy. The subureteral Teflon injection (STING) was the first technique described (1). In all the series presented by various authors the success rate depends on the grade of VUR.

In high grade VUR brevity of the ureteral tunnel (intramural tract) is the main reason for the lower efficacy of the STING procedure. Modifications of STING have been proposed, consisting in an intraureteral injection, either with or without preliminary ureteral hydrodistension (2-3).

The intraureteral technique presents some advantages in terms of efficacy, but has a potential risk of ureteral obstruction, mainly in cases of pre-existing ureteral dilatation and kinking. Herein is described a new modification of the STING procedure, consisting in ureteral repositioning and injection (URI).

\section{MATERIALS AND METHODS}

Between January 2006 and December 2006192 children, 5 months to 10 years old (mean age 2.8 years), underwent endoscopic treatment for vesicoureteral reflux with injection of dextranomer/hyaluronic acid copolymer (Dx/HA; Deflux, Q-Med, Uppsala, Sweden). The STING procedure, as described by Puri and O'Donnell, was used in 165 patients (235 ureters). A modified STING procedure (ureteral repositioning and injection) was used in $27 \mathrm{pa-}$ tients (38 ureters).

The Wolf 8/9.8 Ch and the Wolf $10 \mathrm{Ch}$ were used in most cases. The Wolf $14 \mathrm{Ch}$ was used in older children. A rigid 23 gauge "all metal needle" (Q-Med, Uppsala, Sweden) was used in all cases.
STING procedure: according to the original technique, the needle was inserted a few millimetres below the ureteral orifice and the material injected into the terminal submucosal tract of the ureter. In gaping ureteral orifices, the tip of the needle was inserted directly into the meatus, performing an "intraureteral" injection; this technique, as described by P. Frey, was performed without preliminary hydrodistention . The average amount of material used averaged $0.7 \mathrm{ml}$ (0.3-1.8 ml).

Ureteral repositioning and injection (URI): The needle was inserted at 6 o'clock position, as for standard STING, and subsequently the distal part of the ureter was raised and levered towards the lumen of the bladder. Holding the distal ureter in this position, Dx/HA was injected. (Figure 1). The amount of material used averaged $0.4 \mathrm{ml}(0.3-0.8$ $\mathrm{ml})$. It was interesting to notice that the ureter remains in an intravesical position and does not collapse at the end of the procedure (Figure 2).

Follow-up: Children were discharged 24 hours after treatment. Antibiotic prophylaxis was continued for 1 month post-operatively. Follow-up consisted of periodic urinalysis, renal bladder ultrasound 1 month after treatment and voiding cystourethrogram (VCUG) 4-6 months after the procedure. In children having acquired urinary control a mercaptoacetyltriglycine (MAG3) renal scan with indirect voiding cystogram was preferred to traditional fluoroscopic VCUG.

A Student's T test was performed to analyze the data of the two groups of children treated with the two techniques.
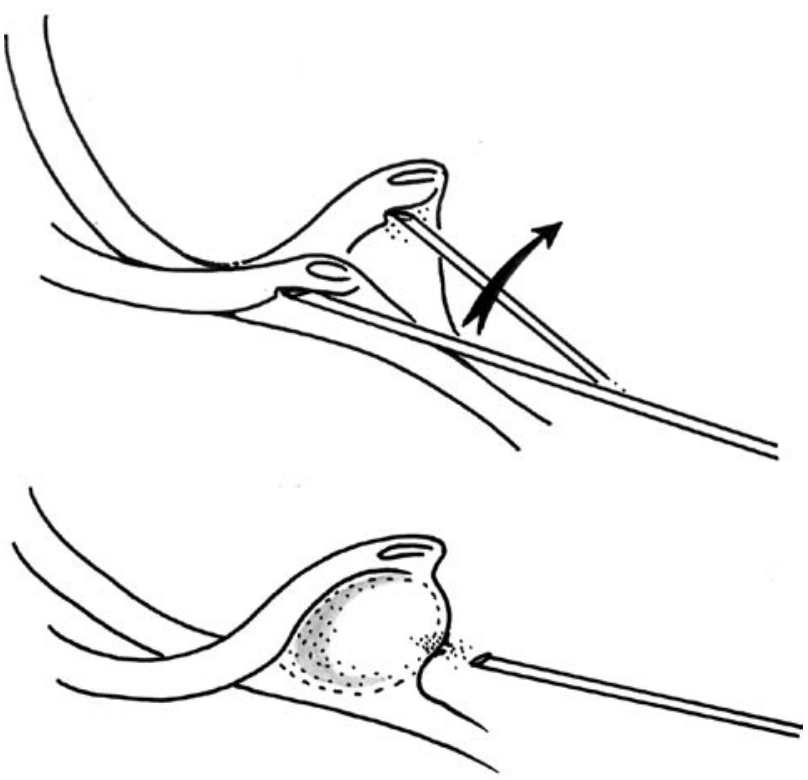

FIGURE 1. Diagram of the "ureteral repositioning and injection" (URI). 


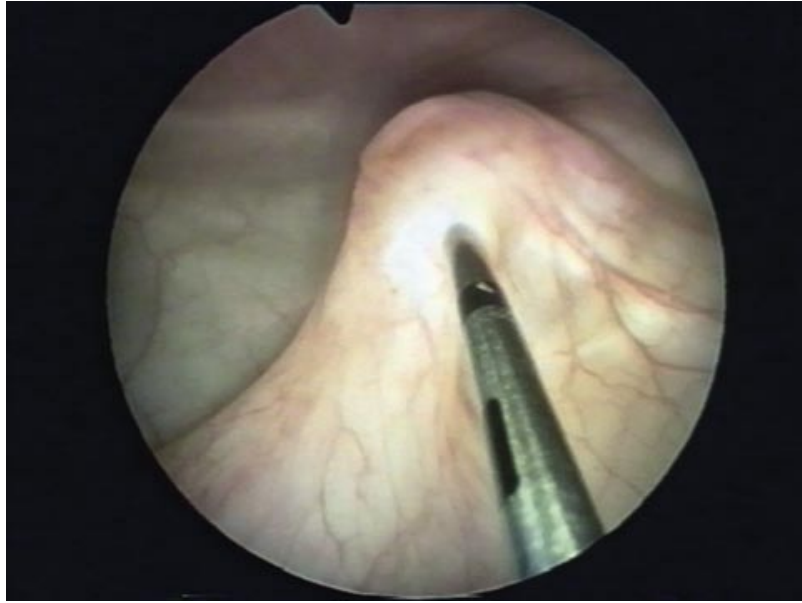

FIGURE 2. Dx/HA implant at the endoscopic view: the ureter remains in an intravesical position and does not collapse at the end of procedure.

\section{RESULTS}

After one injection VCUG performed at 4-6 months follow-up showed no VUR in 203 ureters of the STING group $(86 \%)$ and in 34 ureters of the URI group (91\%). In the STING group the success rate was $90 \%, 88 \%$ and $80 \%$ for grades II, III and IV VUR respectively (Table I).

In the URI group the success rate was $100 \%, 89 \%$ and $82 \%$ for grades II, III and IV VUR (Table II).

We observed a positive trend in the results, even though the difference was not statistically significant. This may be explained by the limited number of patients and the overall small difference between the two groups.

The amount of injected material averaged $0.7 \mathrm{ml}$ (0.3-1.8 $\mathrm{ml}$ ) for the STING and $0.4 \mathrm{ml}(0.3-0.8)$ for the URI procedure.

TABLE I. STING GROUP (SUCCESS RATE). 165 PATIENTS. 235 URETERS.

\begin{tabular}{|c|c|c|c|}
\hline Reflux grade & Ureters & Success & $\%$ \\
\hline II & 50 & 45 & 90 \\
\hline III & 125 & 110 & 88 \\
\hline IV & 60 & 48 & 80 \\
\hline Total & 235 & 203 & 86 \\
\hline
\end{tabular}

\section{DISCUSSION}

Although vesicoureteral reflux is the most common problem in paediatric urology there is controversy about the optimal management of reflux (4-9).

Endoscopic treatment, since its introduction in the 80 s, has become a valid alternative either to antibiotic prophylaxis (in low grade reflux) or to open surgery (in high grade reflux) (5).

Until the late '90s, the overall success rate of endoscopic treatment was rather low compared to open surgery (4). During the past 5 years, the results of endoscopic treatment of VUR have been constantly improving thanks to new injectable materials and improved endoscopic instruments and surgical techniques.

After 21 years of experience with more than 2000 children treated endoscopically we can try to define the reason of the improvement of success rate.

The learning curve cannot be a valid reason since our major advances in endoscopic treatment have been performed in recent years, at least 15 years after our initial experience.

Some authors attributed the improvement of success rate to increasing volumes of implanted material. However, in our experience the volume of implanted material that we employ has decreased during the years, while the success rate that we observe has improved constantly.

The major advance, in our opinion, has been obtained thanks to the use of the metal needle. There are various advantages in using this kind of needle. It allows the operator to perform the procedure without any help by an assistant, with more precision and injecting less amount of material.

Modifications of the original STING procedure may play a role in the improvement of success rate reported in the more recent series of cases. In our experience the intraureteral injection has always been used in gaping ure-

TABLE II. URI GROUP (SUCCESS RATE). 27 PATIENTS. 38 URETERS

\begin{tabular}{|c|c|c|c|}
\hline Reflux grade & Ureters & Success & $\%$ \\
\hline II & 8 & 8 & 100 \\
\hline III & 19 & 17 & 89 \\
\hline IV & 11 & 9 & 82 \\
\hline Total & 39 & 34 & 91 \\
\hline
\end{tabular}


teral orifices. The modified STING procedure proposed by Kirsch, known as hydrodistension injection technique (HIT), represents a further refinement of the intraureteral injection; a hydrodistention of the ureteral orifice allows to define the site of injection within the ureteral submucosa (3).

Although the authors did not report obstruction clinically or sonographically evident, intraureteral injection, combined with the greater volume of material injected, could create the risk of ureteral obstruction.

The modification we have proposed is a combination of ureteral repositioning into the bladder and injection.

This technique has several advantages: first of all, it is very easy to perform; secondly, it allows use of a smaller amount of material $(0.4 \mathrm{ml}$ vs $0.7 \mathrm{ml}$ on average). Furthermore, ureteral repositioning, with the support of the implant, realizes a true flap-valve mechanism, since any minimal increase of bladder pressure makes the ureteral orifice close.

Use of the URI technique has surely contributed to the increased success rate (up to $90 \%$ ) observed in our patient series, even though the difference between results of the URI technique and results of the standard STING is not statistically significant.

The URI technique is now our preferred method of endoscopic treatment of vesicoureteral reflux; it is simple to perform and quite easy to learn: thus we consider it easily applicable to a large number of patients in the future.

\section{REFERENCES AND RECOMENDED READINGS ("of special interest, ${ }^{* *}$ of outstanding interest)}

**1. O’DONNELL, B.; PURI, P.: "Treatment of vesicoureteric reflux by endoscopic injection of Teflon". Br. Med. J., 289: 7, 1984.

2. FREY, P.; JENNY, P.; HERZOG, B.: "Endoscopic subureteric collagen injection (SCIN): A new alternative treatment of vesicoureteric reflux in children. Experience in 82 refluxing ureters". Ped. Surg. Int., 6: 287, 1991.

**3. KIRSCH, A.J.; PEREZ-BRAYFIELD, M.R.; SMITH, E.A.: "The modified STING procedure to correct vesicoureteral reflux: Improved results with submucosal implantation within the intramural ureter". J. Urol., 171: 2413, 2004.

**4. ELDER, J.S.; DIAZ, M.; CALDAMONE, A.A. y cols.: "Endoscopic therapy for vesicoureteral reflux: A metaanalysis. I. Reflux resolution and urinary tract infection". J. Urol., 175: 716, 2006.

**5. CAPOZZA, N.; CAIONE, P.: "Dextranomer/hyaluronic acid copolymer implantation for vesicoureteral reflux: A randomized comparison with antibiotic prophylaxis". J. Pediatr., 140: 230, 2002.

*6. LACKGREN, G.; STENDBERG, A.; WAHLIN, N.: "Long-term follow-up of children treated with dextranomer/hyaluronic acid copolymer for vesicoureteral reflux". J. Urol., 166: 1887, 2001.

7. YUCEL, S.; UCAR, M.; GUNTEKIN, E. y cols.: "The effect of location of the ureteric orifice on the efficacy of endoscopic injection to correct vesico-ureteric reflux". BJU Int., 95: 1314, 2005.

*8. CAPOZZA, N.; LAIS, A.; MATARAZZO, E. y cols.: "Influence of voiding dysfunction on the outcome of endoscopic treatment for vesicoureteral reflux". J. Urol., 168: 1695, 2002.

*9. ELDER, J.S.: "Pediatric vesicoureteral reflux guidelines panel summary: Report on the management of primary vesicoureteral reflux in children". J. Urol., 1846, 1997. 